\title{
Toxoplasma gondii (Nicolle et Manceaux, 1908) detected in Dermacentor reticulatus (Fabricius) (Ixodidae)
}

\author{
${ }^{1}$ Department of Health Biohazards and Parasitology, Institute of Rural Health, Lublin, Poland; \\ ${ }^{2}$ Department of Parasitology, National Veterinary Research Institute in Pulawy, Pulawy, Poland
}

Angelina Wójcik-Fatla ${ }^{1}$, Jacek Sroka $^{1,2}$, Violetta Zając ${ }^{1}$, Anna Sawczyn $^{1}$, Ewa Cisak $^{1}$ and Jacek Dutkiewicz ${ }^{1}$

\begin{abstract}
The aim of the present work was to determine whether Dermacentor reticulatus (Fabricius), tick species common in eastern Poland could be infected with Toxoplasma gondii (Nicolle et Manceaux, 1908). A total of 664 unfed D. reticulatus ticks were collected from six localities of Lublin province (eastern Poland) within the framework of study for the presence of bacterial, viral and parasitological infections, with use of PCR and confirmed by sequencing analysis. The prevalence of $T$. gondii DNA of B1 gene in the total examined $D$. reticulatus ticks was $3.2 \%$. The infection varies greatly depending on the locality of tick collection $(0-16.7 \%)$. Preliminary identification of clonal type (I or II/III) by Restriction Fragments Length Polymorphism PCR (RFLP-PCR) with use B1 gene showed that all isolates of $T$. gondii belonged to type I. RFLP analysis using genetic markers SAG1, 5'-SAG2, 3'-SAG2, SAG3, and GRA6 on B1-positive samples showed that only a single isolate proved to be type I with all five markers, another type was classified to type I according to four markers, while another five isolates had only type I alleles at GRA6, which cannot be regarded as type I confirmation. It must be pointed out that the used DNA isolation method by boiling with ammonium hydroxide enables to receive the total DNA from ticks, but may be not quite suitable for genotyping. In conclusion, this study indicates that besides Ixodes ricinus (Linnaeus), also D. reticulatus should be considered as a potential vector of $T$. gondii. The presumption of tick-borne transmission as an alternative pathway of disease spreading could well explain the high prevalence of toxoplasmosis among the herbivorous mammals and birds. However, this hypothesis needs verification by further experimental and ecological studies.
\end{abstract}

Keywords: toxoplasmosis, vectors, ticks, Poland, PCR, RFLP-PCR

Toxoplasma gondii (Nicolle et Manceaux, 1908) is an obligatory intracellular parasitic protist within the phylum Apicomplexa, family Sarcocystidae - Perkins et al. (2000). Until recently, the sexual reproduction of the parasite has been observed only in the intestine of felids, which are definitive hosts of $T$. gondii, while a large number of other mammalian and bird species have been identified as intermediate hosts, which are commonly infected with this protist. In humans, the parasite causes toxoplasmosis, a usually asymptomatic zoonotic disease which, however, may pose a severe medical problem as a congenital infection causing cerebral and ocular damage in newborns and as an acquired infection in immunocompromised individuals, such as AIDS patients (Dubey and Beattie 1988).

Three main genotypes are responsible for the majority of human infections: type I strains are associated with severe or atypical ocular toxoplasmosis in immunocompetent adults and are represented in congenital infections; type II responds for most clinical toxoplasmosis cases in immunocompromised patients and has been also isolated in cases of congenital toxoplasmosis; type II and III strains are often isolated from animals. Additional genotypes, such as genotype 'A' (atypical) are also recognised, but appear to be less common (Howe and Sibley 1995, Dardé 1996, Grigg et al. 2001, Miller et al. 2008).

Oral transmission by consumption of raw meat containing parasite cysts or by consumption of food and water contaminated with cat faeces containing $T$. gondii oocysts is regarded as the main route of primary infection. However, this route hardly explains the common occurrence of T. gondii in a variety of hosts, such as herbivorous mammals, wild rodents and birds that are unlikely to contract primary infection orally with meat or cat faeces. Thus, some additional routes of transmission suggested by earlier authors and partly forgotten should nowadays be reconsidered, including infection by skin lesions and transmission by arthropods (Deryło et al. 1978).

A number of earlier studies indicated that ticks (Ixodida) may be potential vectors of T. gondii (see Gidel and Provost 1965, Singh et al. 1965). Deryło et al. (1978), provided evidence that the hard tick Ixodes ricinus (Linnaeus) may participate in the transmission of this protist. The presumptive role of $I$. ricinus as potential vectors of $T$. gondii has been confirmed by more recent studies carried out by our group with the use of polymerase chain reaction (PCR). The presence of $T$. gondii in ticks was confirmed by the

Address for correspondence: J. Sroka, Department of Health Biohazards and Parasitology, Institute of Rural Health, Jaczewskiego 2, 20-090 Lublin, Poland. Phone: +48 817184555; Fax:+48 817478 646; E-mail: jacek.sroka@piwet.pulawy.pl 
Table 1. Presence of Toxoplasma gondii (Nicolle et Manceaux, 1908) DNA in Dermacentor reticulatus (Fabricius) collected in various localities on the territory of Lublin province (eastern Poland).

\begin{tabular}{lccc}
\hline Locality & Males & Females & Total \\
\hline Suchawa (A) & $0 / 84(0)$ & $2 / 99(2 \%)$ & $2 / 183(1 \%)$ \\
Sobibór (B) & $6 / 23(26 \%)$ & $5 / 43(12 \%)$ & $11 / 66(17 \%)$ \\
Poleski National Park (C) & $0 / 86(0)$ & $0 / 114(0)$ & $0 / 200(0)$ \\
Ostrów Lubelski (D) & $3 / 67(5 \%)$ & $1 / 81(1 \%)$ & $4 / 148(3 \%)$ \\
Nielisz (E) & $0 / 17(0)$ & $1 / 29(3 \%)$ & $1 / 46(2 \%)$ \\
Wilków (F) & $1 / 9(11 \%)$ & $2 / 12(17 \%)$ & $3 / 21(14 \%)$ \\
\hline Total & $10 / 286(4 \%)^{* *}$ & $11 / 378(3 \%)^{* *}$ & $21 / 664(3 \%)^{* *}$ \\
$*$ infected/examined (prevalence); ** prevalence of infection significantly depending on the locality: P $<0.000001$.
\end{tabular}

detection its DNA in tissues of mice inoculated with the homogenate of I. ricinus ticks harvested from the natural environment (Sroka et al. 2003, 2008).

The aim of the presented study was to determine whether Dermacentor reticulatus (Fabricius), another tick species common in eastern Poland, could be infected with T. gondii.

\section{MATERIALS AND METHODS}

Collection of ticks. A total of 664 unfed Dermacentor reticulatus ticks (378 females and 286 males) were collected during the spring season (between March-May in 2011 and 2012) in the following localities situated on the territory of the Lublin province (eastern Poland): Suchawa (locality A), Sobibór (locality B), Poleski National Park (locality C), Ostrów Lubelski (locality D), Nielisz (locality E) and Wilków (locality F). Ticks were collected by dragging a woollen flag over the lower vegetation and litter along the paths and edges of deciduous and mixed forests. Only adult ticks (females and males) were collected. Collected ticks were placed alive in glass tubes for further investigation.

DNA isolation from ticks. Total DNA was isolated from the adult ticks separately by the ammonia method (Rijpkema et al., 1996). The concentration of DNA in the isolates was determined with a NanoDrop ND1000 Spectrophotometer (USA). The determined DNA concentrations ranged $520-672 \mathrm{ng} / \mu 1$ for males and $670-878 \mathrm{ng} / \mu 1$ for females of $D$. reticulatus. The obtained lysates were stored at $-20^{\circ} \mathrm{C}$ for further examination.

Detection of Toxoplasma gondii DNA (B1 fragment gene) by PCR and RFLP-PCR methods. Detection of $T$. gondii DNA, based on the amplification of 35-fold-repetitive gene $\mathrm{B} 1$ fragment in the two following nested PCR reactions, was performed by a method according to Grigg and Boothroyd (2001). Each PCR reaction (50 $\mu$ l of total volume) contained 1.5 U Taq DNA polymerase (Qiagen, Valencia, California, USA), a set of primers: $\mathrm{Pml} / \mathrm{S} 1$ and Pml/AS1 or Pml/S2 and Pml/AS2, dNTPs in a final concentration of $0.1 \mathrm{mM}$, nuclease-free water and $5 \mu \mathrm{l}$ of isolated DNA. The amplification was carried out in a C1000 Thermal Cycler (BioRad, Hercules, California, USA). Products of amplification (531 bp) were identified in 2\% agarose gel (Basica LE, Prona, Madrid, Spain), after electrophoresis in standard conditions and staining with ethidium bromide solution $(2 \mu \mathrm{g} / \mathrm{ml})$. As positive controls, the $T$. gondii DNA isolates of RH (type I), ME49 (type II) and C56 (type III) strains were used. The nuclease free water was used as the negative control. For preliminary identification the genotype (I or II/III) of the isolated $T$. gondii strains, RFLP-PCR was performed. The amplified B1 products were digested with restriction enzymes Eco 721 (PmII) and XhoI
(Thermo Scientific, Vilnius, Lithuania), and identified on 2.5\% agarose gel (Basica LE).

DNA sequencing. DNA sequencing of the B1 gene fragment of T. gondii was performed with ABI PRISM 310 Genetic Analyzer (Applied Biosystems, Inc., Foster City, CA, USA) using an Abi Prism Big Dye Terminator v. 3.1. Cycle Sequencing Kits and Big Dye XTerminator Purification Kit (Applied Biosystems). The results were compared with sequences in the GenBank database using the BLAST server at the National Center for Biotechnology Information (Rockville Pike, Bethesda, Maryland, USA).

Multiplex and RFLP-PCR. For further genetic characterisation of the B1 gene positive samples, multiplex PCR was performed using genetic markers SAG1, SAG2 (5'-SAG2 and 3'-SAG2), SAG3 and GRA6 according to Dubey et al. (2006). The amplification was carried out in a C1000 Thermal Cycler (BioRad). Positive and negative controls for each reactions was used as mentioned above. Products of amplification were identified in $2 \%$ agarose gel after electrophoresis in standard conditions and staining with ethidium bromide solution $(2 \mu \mathrm{g} / \mathrm{ml})$. Amplification products were digested by restriction enzymes, according to the protocol of the enzymes producer (Thermo Scientific). RFLP patterns were identified in $2.5 \%$ agarose gel.

Statistical analysis. Data were analysed by $\chi^{2}$-test, with the use of STATISTICA for Windows v. 5.0 package (StatSoft Inc., Tulsa, Oklahoma, USA). The value $\mathrm{p}<0.05$ was considered significant.

\section{RESULTS}

The prevalence of the Toxoplasma gondii DNA of the B1 gene in Dermacentor reticulatus was 3.2\% (Table 1). No significant difference could be found between the prevalence of infection in males and females (respectively, $3.5 \%$ and $2.9 \% ; \mathrm{P}=0.662$ ). In contrast, the infection varies greatly depending on the locality of tick collection and this association was highly significant in males $\left(\chi^{2}=173.22\right.$; $\mathrm{P}<0000001)$, females $\left(\chi^{2}=96.03 ; \mathrm{P}<0.000001\right)$ and total ticks $\left(\chi^{2}=100.43 ; \mathrm{P}<0.000001\right)$. This dependence was mostly due to the high prevalence of infection in two localities (Wilków and Sobibór), accounting for 14.3-16.7\%, whereas prevalence was much lower in the remaining four localities, ranging from $0.0-2.7 \%$ (Table 1 ).

The sequence analysis of samples positive for the B1-gene confirmed that the amplified products showed 100\% homology with Toxoplasma gondii (GenBank: AF179871.1). RFLP analysis on B1-positive samples showed that all Toxoplasma isolates from D. reticulatus belonged to Type I (not digested by Eco721 nor XhoI). 
Analysis with the multiplex PCR method showed that the identification with all 5 markers (GRA6, 3'SAG2, 5'SAG2, SAG3 and SAG1) was possible only for a single isolate (a female from Sobibór), which proved to be type I. Another (a male from Sobibór) was classified to type I according to 4 markers (GRA6, 3'SAG2, 5'SAG2 and SAG3, without SAG1). The other 5 isolates ( 2 females from Sobibór and Ostrów Lubelski and 3 males from Ostrów Lubelski) had type I alleles at GRA6. The primary classification of the $T$. gondii isolates by RFLP-PCR as belonging to Type I must therefore be assumed with caution.

\section{DISCUSSION}

Dermacentor reticulatus is a common tick in eastern Poland identified as a potential vector of numerous pathogens in this area, such as tick-borne encephalitis virus (TBEV) (Wójcik-Fatla et al. 2011), Babesia microti (Fran ça, 1909) (see Wójcik-Fatla et al. 2012) and spotted fever group rickettsiae (SFGR) (Wójcik-Fatla et al. 2013). The presented results indicate that besides Ixodes ricinus, also Dermacentor reticulatus should be considered as a potential vector of Toxoplasma gondii, although seemingly with a lower infection rate compared to the aforementioned tick species (Sroka et al. 2008, 2009).

Nevertheless, the presented hypothesis about the possible role of ticks in the epidemiology of toxoplasmosis must be regarded with some caution, because some authors were not successful in isolating $T$. gondii from ticks collected in natural habitats or in experimental transmission of the infection by these arachnids (Jagow and Hoffmann 1970, Gill et al. 1971). It is also not known which stage(s) of $D$. reticulatus might be involved in the transmission of $T$. gondii and how the life cycle of parasites looks in the tick body. In this work, T. gondii DNA was found only in the adult ticks; however, in an earlier study, Deryło et al. (1978) evidenced the transmission of $T$. gondii by intermittent blood sucking of $I$. ricinus nymphs, but not larvae and females. In the present study, no D. reticulatus nymphs were found and the natural infection rate of this stage remains unknown and needs elucidation.

Dermacentor reticulatus occurs mostly in eastern Poland, but its range and abundance is steadily increasing and in many localities it is more numerous than $\mathrm{I}$. ricinus - Mierzejewska et al. (2015). This is a three-host tick species, which means that the individual stages (larvae, nymphs, adults) feed on different hosts: larvae on small mammals (rodents and insectivorous), nymphs on small mammals and medium-size animals (such as lagomorphs), and adults mostly on cattle and big wild ruminants (usually on elks), but they could attack also humans (Estrada-Peña and Jongejan 1999). The current findings of the DNA of T. gondii in unfed (questing) adult ticks suggests the possibility of vertical transmission of pathogen, which could be trans-stadial or even transovarial. This could explain, at least in part, the common occurrence of toxoplasmosis in small mammals and big herbivorous animals, which are unlikely to contract the infection orally with meat or cat faeces, but could be infected by the bite of infected larvae and nymphs (in the case of small mammals) or adults (in the case of big herbivorous animals). Another possibility of infection is accidental eating of an infected tick. Nevertheless, for elucidation of all the questions concerning the possible transmission of $T$. gondii by $D$. reticulatus ticks, further studies are needed that should comprise isolation of virulent strains and experimental work for assessment of the mode of tick infection and the probability of trans-stadial and transovarial transmission.

The population structure of T. gondii is oligoclonal, characterised by three main lineages: type I, II and III. According to $\mathrm{Su}$ et al. (2006), the intraspecies differentiation of $T$. gondii exceeds this classification worldwide, but not in Europe. Type II of $T$. gondii is the most prevalent genotype isolated in Europe in animals (Herrmann et al. 2010, Burrells et al. 2013) and humans (Ajzenberg et al. 2002, Nowakowska et al. 2006). Type I was also reported in European countries from farm and wild animals and also from cases of human toxoplasmosis (Aspinall et al. 2003, Berger-Schoch et al. 2011, Burrells et al. 2013, Turčeková et al. 2014). However, type I is actually rarely detected in Europe and various studies conducted in animals and humans showed a predominance $(>95 \%)$ of type II (Ajzenberg et al. 2009, 2010). There is not clear evidence about the relation between disease symptoms and parasite genotypes. Type I isolates are more likely to be involved in severe toxoplasmic retinochoroiditis in human patients; also, atypical isolates often cause severe acute toxoplasmosis in immunocompetent patients (Khan et al. 2005, Su et al. 2010).

In the present study, RFLP analysis on B1-positive samples showed that only a single isolate proved to be type I with all five markers, another was classified to type I according to four markers, while another five isolates had type I alleles only at GRA6, which cannot be regarded as confirmation as being type I. These incomplete results may be due, at least in part, to the DNA isolation with the ammonia method which is not quite suitable for genotyping. Thus, primary classification of $T$. gondii isolates by RFLPPCR as belonging to type I must be assumed with caution. The $T$. gondii strains belonging to genotype I were earlier also found commonly with the use of RFLP-PCR in I. ricinus (Sroka et al. 2008, 2009), but in contrast to the present work, I. ricinus ticks harbored also strains belonging to II/ III genotypes and strains preliminary classified as 'atypical'.

Summarising, the presented results suggest that ticks could be considered as potential vectors of toxoplasmosis. This presumption has been confirmed recently by other studies. Thus, Tanaka et al. (2012), proved experimentally in Japan that the ticks Haemaphysalis longicornis (Neumann) can harbour $T$. gondii, which suggests that the ticks may participate in the spreading of toxoplasmosis. These authors expressed the opinion that the infection induces in ticks synthesis of the antimicrobial peptide longicin belonging to the group of defensins. In a recent study from Sosnowiec, Poland, a very high percentage $(65 \%)$ of $I$. ricinus ticks collected in Silesia (southwest Poland) showed the presence of $T$. gondii DNA (Asman et al. 2015).

In conclusion, the current study indicates that besides I. ricinus, also D. reticulatus should be considered as a po- 
tential vector of $T$. gondii. The presumption of tick-borne transmission as an alternative pathway for the spreading of the disease could well explain the high prevalence of toxoplasmosis among herbivorous ungulates, small mammals and birds. However, this hypothesis needs verification by further experimental and ecological studies.

Acknowledgements. This study was supported by National Science Centre Grant: N N404 267640.

\section{REFERENCES}

Ajzenberg D., Cogne N., Paris L., Bessieres M.H., Thulliez P., Filisetti D. Pelloux H., Marty P., Dardé M.L. 2002: Genotype of 86 Toxoplasma gondii isolates associated with human congenital toxoplasmosis, and correlation with clinical findings. J. Infect. Dis. 186: 684-689.

Ajzenberg D., Collinet F., Mercier A., Vignoles P., Dardé M.L. 2010: Genotyping of Toxoplasma gondii isolates with 15 microsatellite markers in a single multiplex PCR assay. J. Clin. Microbiol. 48: 4641-4645.

Ajzenberg D., Yera H., Marty P., Paris L., Dalle F., Menotti J., Aubert D., Franck J., Bessières M.H., Quinio D., Pelloux H., Delhaes L., Desbois N., Thulliez P., Robert-Gangneux F., Kauffmann-Lacroix C., Pujol S., Rabodonirina M., Bougnoux M.E., Cuisenier B., Duhamel C., Duong T.H., Filisetti D., Flori P., Gay-Andrieu F., Pratlong F., Nevez G., Totet A., Carme B., Bonnabau H., Dardé M.L., Villena I. 2009: Genotype of 88 Toxoplasma gondii isolates associated with toxoplasmosis in immunocompromised patients and correlation with clinical findings. J. Infect. Dis. 199: 1155-1167.

Asman M., Solarz K., Cuber P., Gąsior T., Szilman P., Szilman E., Tondaś E., Matzullok A., Kusion N., Florek K. 2015: Detection of protozoans Babesia microti and Toxoplasma gondii and their co-existence in ticks (Acari: Ixodida) collected in Tarnogórski district (Upper Silesia, Poland). Ann. Agric. Environ. Med. 22: 80-83.

Aspinall T.V., Guy E.C., Roberts K.E., Joynson D.H., Hyde J.E., Sims P.F. 2003: Molecular evidence for multiple Toxoplasma gondii infections in individual patients in England and Wales: public health implications. Int. J. Parasitol. 33: 97-103.

Berger-Schoch A.E., Herrmann D.C., Schares G., Müller N., Bernet D. 2011: Prevalence and genotypes of Toxoplasma gondii in feline faeces (oocysts) and meat from sheep, cattle and pigs in Switzerland. Vet. Parasitol. 177: 290-297.

Burrells A., Bartley P.M., Zimmer I.A., Roy S., Kitchener A.C., Meredith A., Wright S.E., Innes E.A., Katzer F. 2013: Evidence of the three main clonal Toxoplasma gondii lineages from wild mammalian carnivores in the UK. Parasitology 140: $1768-1776$.

DARDÉ M.L. 1996: Biodiversity in Toxoplasma gondii. Curr. Top. Microbiol. Immunol. 219: 27-41.

DeryŁo A., Toś-Luty S., Dutkiewicz J., Umiński J. 1978: [Participation of Ixodes ricinus L. in the biology and transmission of Toxoplasma gondii.] Wiad. Parazytol. 24: 585-595. (In Polish.)

Dubey J.P., Beattie C.P. 1988: Toxoplasmosis of Animals and Man. CRC Press, Boca Raton, FL, pp. 41-49.

Dubey J.P., Patitucci A.N., Su C., Sundar N., Kwok O.C., SHEN S.K. 2006: Characterization of Toxoplasma gondii isolates in free-range chickens from Chile, South America. Vet. Parasitol. 140: 76-82.

Estrada-Peña A., Jongejan F. 1999: Ticks feeding on humans: a review of records on human-biting Ixodoidea with special reference to pathogen transmission. Exp. Appl. Acarol. 23: 685-715.

Gidel R., Provost A. 1965: Isolement de Toxoplasma gondii chez des Ixodidés du genre Amblyomma naturellement infectés. Ann. Inst. Pasteur (Paris) 109: 613-616.

Gill H.S., Nair E., Prakash O. 1971: Natural infection of Toxoplasma gondii sought in ticks. Ind. J. Med. Res. 59: 1035-1038.

Grigg M.E., Boothroyd J.C. 2001: Rapid identification of virulent type I strains of the protozoan pathogen Toxoplasma gondii by PCR restriction fragment length polymorphism analysis at the B1 gene. J. Clin. Microbiol. 39: 398-400.

Grigg M.E., Ganatra J., Boothroyd J.C., Margolis T.P. 2001: Unusual abundance of atypical strains associated with human ocular toxoplasmosis. J. Infect. Dis. 184: 633-639.

Herrmann D.C., Pantchev N., Vrhovec M.G., Barutzki D., Wilking H., Frohlich A., Luder C.G.K., Conraths F.J., SChares G. 2010: Atypical Toxoplasma gondii genotypes identified in oocysts shed by cats in Germany Int. J. Parasitol. 40: 285-292.

Howe D.K., Sibley L.D. 1995: Toxoplasma gondii comprises three clonal lineages: correlation of parasite genotype with human disease. J. Infect. Dis. 172: 1561-1566.

JAGOW M., HoffmanN G. 1970: Untersuchungen zur Übertragung von Toxoplasma gondii durch verschiedene Entwicklungsstadien von Ornithodoros moubata. Z. Parasitenkd. 33: 246-251.

Khan A., Su C., German M., Storch G.A., Clifford D.B., Sibley L.D. 2005: Genotyping of Toxoplasma gondii Strains from immunocompromised patients reveals high prevalence of type I strains. J. Clin. Microbiol. 43: 5881-5887.

Mierzejewska E.J., Welc-Faleciak R., Karbowiak G., KowALec M., Behnke J.M., Bajer A. 2015: Dominance of Dermacentor reticulatus over Ixodes ricinus (Ixodidae) on livestock, companion animals and wild ruminants in eastern and central Poland. Exp. Appl. Acarol. 6: 83-101.

Miller M.A., Miller W.A., Conrad P.A., James E.R., Melli A.C., Leutenegger C.M., Dabritz H.A., PaCkham A.E., Paradies D., Harris M., Ames J., Jessup D.A., Worcester K., Grigg M.E. 2008: Type X Toxoplasma gondii in a wild mussel and terrestrial carnivores from coastal California: new linkages between terrestrial mammals, runoff and toxoplasmosis of sea otters. Int. J. Parasitol. 38: 1319-1328.

Nowakowska D., Colón I., Remington J.S., Grigg M., Golab E., Wilczynski J., Sibley L.D. 2006: Genotyping of Toxoplasma gondii by multiplex PCR and peptide-based serological testing of samples from infants in Poland diagnosed with congenital toxoplasmosis. J. Clin. Microbiol. 44: 1382-1389.

Perkins F.O., Barta J.R., Clopton R.E., Peirce M.A., Upton S.J. 2000: Phylum Apicomplexa Levine, 1970. In: J.J. Lee, G.F. Leedale and P. Bradbury (Eds.), An Illustrated Guide to the Protozoa, Second Edition, Volume 1. Society of Protozoologists, Lawrence, Kansas, pp. 190-369.

Rijpkema S., Golubic D., Moelkenboer M., Verbeek-De Kruif N., Schellekens J. 1996: Identification of four genomic groups of Borrelia burgdorferi sensu lato in Ixodes ricinus ticks collected in a Lyme borreliosis endemic region of northern Croatia. Exp. Appl. Acarol. 20: 23-30.

Singh I., Basu S.M., Narsimhan D., Sardana D.N., Kapila C.C., Varma R.N., Rao K.N.A., Chopra S.K., Karani N.D.P. 1965: Haemorrhagic disease following tick bites suspected toxoplasmosis. Lancet 17: 834-838.

Sroka J., Chmielewska-Badora J., Dutkiewicz J. 2003: $I x$ odes ricinus as a potential vector of Toxoplasma gondii. Ann. Agric. Environ. Med. 10: 121-123.

Sroka J., Szymańska J., Wójcik-Fatla A. 2009: The occurrence of Toxoplasma gondii and Borrelia burgdorferi sensu lato in Ixodes ricinus ticks from eastern Poland with the use of PCR. Ann. Agric. Environ. Med. 16: 313-319.

Sroka J., Wójcik-Fatla A., Zwoliński J., Zając V., SAwCZuk M., Dutkiewicz J. 2008: Preliminary study on the occurrence of Toxoplasma gondii in Ixodes ricinus ticks from north-west- 
ern Poland with the use of PCR. Ann. Agric. Environ. Med. 15: 333-338.

Su C., Shwab E.K., Zhou P., Zhu X.Q., Dubey J.P. 2010: Moving towards an integrated approach to molecular detection and identification of Toxoplasma gondii. Parasitology 137: 1-11.

Su C., Zhang X., Dubey J.P. 2006: Genotyping of Toxoplasma gondii by multilocus PCR-RFLP markers: A high resolution and simple method for identification of parasites. Int. J. Parasitol. 36: 841-848

Tanaka T., Maeda H., Galay R.L., Boldbattar D., Umemiya-Shirafuji R., Suzuki H., Xuan X., Tsuji N., Fujisaki K. 2012: Tick longicin implicated in the arthropod transmission of Toxoplasma gondii. J. Vet. Sci. Technol. 3: 112.

Turčeková L., Hurníková Z., Spišák F., Miterpáková M., Chovancová B. 2014: Toxoplasma gondii in protected wildlife in the Tatra National Park (TANAP), Slovakia. Ann. Agric. Environ. Med. 21: 235-238.

Wojcik-Fatla A., Bartosik K., Buczek A., Dutkiewicz J. 2012: Babesia microti in adult Dermacentor reticulatus ticks from eastern Poland. Vector Borne Zoon. Dis. 12: 841-843.

Wójcik-Fatla A., Cisak E., Zając V., Sroka J., Sawczyn A., DutKiewicZ J. 2013: Study on tick-borne rickettsiae in eastern Poland. I. Prevalence in Dermacentor reticulatus (Acari: Amblyommidae). Ann. Agric. Environ. Med. 20: 276-279.

Wójcik-Fatla A., Cisak E., Zając V., Zwoliński J., DutkiewICZ J. 2011: Prevalence of tick-borne encephalitis virus in Ixodes ricinus and Dermacentor reticulatus ticks collected from the Lublin region (eastern Poland). Ticks Tick-Borne Dis. 2: 16-19.

Cite this article as: Wójcik-Fatla A., Sroka J., Zając V., Sawczyn A., Cisak E., Dutkiewicz J. 2015: Toxoplasma gondii detected in Dermacentor reticulatus ticks. Folia Parasitol. 62: 055. 